\title{
Apresentação do Dossiê Polifonias em saberes: música, educação e história
}

INÊS DE ALMEIDA ROCHA IDa

EDNARDO MONTEIRO GONZADA DO MONTI ID b

Atendendo à uma demanda crescente na área de estudos sobre ensino, aprendizagem e música, seja em espaços institucionalizados ou não, seja em modalidades formais, não-formais ou informais, o Dossiê Polifonias em saberes: música educação e história reúne textos com temáticas musicais, trabalhados com enfoque histórico, que abordam aspectos relacionados ao ensino e aprendizagem de saberes musicais. Os pesquisadores se ocuparam, mais especificamente, de assuntos relacionados à itinerários formativo de musicistas, docentes e discentes; analisaram o ensino de música em espaços escolares; estudaram como uma trajetória formativa leva um musicista a tornar-se docente; indagaram sobre performance em banda como fator educativo e socializador; investigaram sobre livro como fonte de pesquisa para compreender aspectos da cultura musical do século XIX; analisaram repertório musical para o ensino de piano; acompanharam trajetória de mulheres compositoras e a escolarização da música na Educação Básica.

O marco temporal do conjunto de pesquisas abarca estudos do século XIX, XX e XXI, evidenciando que, de uma forma geral, embora com exceções, a área ainda se ocupa de reflexões abrangendo longas durações temporais. O ensino da música em períodos anteriores ao século XIX continua sendo uma grande lacuna a ser preenchida.

Em relação às fontes de pesquisa, os investigadores elegeram trabalhar com entrevistas orais, hemerotecas físicas e digitais, publicações acadêmicas e livros de referências. Destaca-se a utilização de memórias pessoais escritas pelo pesquisador sendo incorporadas e utilizadas de forma sistematizada e metodologicamente formalizada nas investigações.

Os referenciais teóricos utilizados, de uma forma geral -e se forem pensados por grandes áreas-, demonstram como essas pesquisas valorizam pensadores da área de História Social e História da Educação. Porém, já emergem autores que analisam especificamente temáticas relacionadas à História da Educação Musical, como Monti (2015), Penna (2013), Jardim (2009, 2012), Fonterrada (2008), Rocha (2011) e Queiroz (1998).

a Colégio Pedro II (CPII); Programa de Pós-Graduação em Música da Universidade Federal do Estado do Rio de Janeiro (UNIRIO), Rio de Janeiro, RJ, Brasil. Professora Titular de Educação Musical, e-mail: ines.rocha@unirio.br

${ }^{1}$ Universidade Federal do Piauí - UFPI, Professor do Curso de Licenciatura em Música e do Programa de Pós-graduação em Educação - PPGEd

Rev. Caminhos da Educação: diálogos, culturas e diversidades, Teresina, v. 3, n. 1, p. 2-3, jan./abr. 
Iniciamos o Dossiê com o texto de Marcia Pereira de Oliveira, De arrepiar: a musicista piauiense Gislene Danielle e suas artes - canto, interpretação, docência, que narra o percurso formativo da musicista negra Gislene Danielle, cuja trajetória é mesclada por atuação como cantora e atriz até dedicar-se à carreira docente da rede pública e privada no Estado do Piauí.

Música e banda: tessitura da inserção social no Piaui (1905-1948), de autoria de Pedro Thiago Costa Melo, apresenta análise sobre bandas de música no estado do Piaú, entre os anos de 1905 e 1948, conectando concepção de civilizar com ações educativas em diferentes espaços de sociabilidades. Destaca-se a utilização de fontes hemerográficas.

Para o estudo sobre formação superior docente a partir de fontes orais, João Valter Ferreira Filho desenvolve em A fundação da Licenciatura em Música da Universidade Federal de Campina Grande: apontamentos históricos, uma análise da criação do curso e a importância da universidade para a educação musical local.

O “amor" pela Música: um Dicionário e a cultura musical como pedagogia no século XIX, de Gilberto Vieira Garcia é um estudo a partir de um livro de referência que problematiza interfaces entre cultura musical e pedagogia no ideário do século XIX, utilizando as categorias de análise de programa institucional (Dubet, 2002), regime de amadorismo (Fauquet e Hennion, 2000) e cultura como pedagogia (Silva, 2005).

Tratando de temática pouco explorada Marco Antônio Toledo Nascimento e Priscila de Araujo Garcez, revelam como compositoras de música sacra desenvolveram relevantes trabalhos no ensino de música. Polifonia da fé protestante: a Música Sacra como elemento educativo em Henriqueta Rosa Fernandes Braga (1961), analisam a partir de textos e hinários publicados por essa compositora, concepções, valores e estratégias pedagógicas de sua práxis em igrejas evangélicas.

O repertório pianístico dos programas de recitais de alunos da EMEM (2001 2010) é um texto que trata da música para piano executada no estado do Maranhão no século XX. A longa duração, se justifica pelo fato de existirem evidências de intensa prática pianística no local durante este período. $\mathrm{O}$ arquivamento da documentação, programas de recitais, possibilitou o estudo.

Com o objetivo de desvelar aspectos eurocêntricos e conservadores das práticas educativas da Educação Básica no Brasil, Wladimir de Oliveira Marques e Monique Andries Nogueira apresentam estudo intitulado $O$ ensino de música nas escolas brasileiras, da Colônia à Ditadura civil-militar: faces do conservadorismo. O estudo apresenta apropriação de diversos autores relevantes para a História da Educação Musical no Brasil.

Destaques com enfoque histórico social no ensino de música em escolas do Município de Duque de Caxias (RJ) durante o século $X X$ relata pesquisa sobre aulas, eventos e atividades de educação musical, no âmbito do projeto Casa de Iniciação às Artes (CIART). Eduardo Teixeira Destord e Inês de Almeida Rocha analisam a inserção da música nas escolas públicas do município de Duque de Caxias, no estado do Rio de Janeiro, a partir de diferentes fontes, para compreender os diferentes significados atribuídos às práticas em educação musical.

Em trágicos tempos pandêmicos, registramos nosso sentimento de pesar pelo sofrimento e saudade que abala inúmeras famílias em nosso país e nosso planeta. Com a mesma intensidade, celebremos a vida a cada novo amanhecer e a cada novo anoitecer.

Fica o convite à leitura e o desejo que estes estudos possam provocar muitas outras possibilidades de se contar histórias da educação musical no Brasil. 